ISSN (Print) : 1412-7601

ISSN (Online) : 2654-8712

Volume 6, No.2 September 2020

http://www.ekonobis.unram.ac.id

EKONOBIS

\title{
Analisis Efisiensi Dan Nilai Tambah Produk Agroindustri Olahan Kerupuk Kulit Sapi (Studi Kasus Di Seganteng Kota Mataram)
}

\section{Suprianto, Sarifudin.}

Universitas Mataram

\section{ARTICLE INFO}

Keywords :

Business Efficiency and

Agro-Industry Value

Added Processing
ABSTRACT : This research takes the title "Analysis of Efficiency and Added Value of Processed Agroindustry Products of Cow Crackers (Case Study in Seganteng Mataram City). This research was conducted by taking 6 business units, namely the business of processing cow crackers in Seganteng, Sandubaya Subdistrict, Mataram City, which were determined intentionally. The purpose of this study is to analyze production costs and expenditure levels, cost efficiency and value added or Value Added Ratio (RNT). Overall, of the 6 agro-industry business units for making crackers, while the level of business ratio ( $R$ / C Ratio), the average value is above 1 or $R / C$. The ratio is $>1$, which is meant by both the business of processing skin crackers $(R / C$ Ratio $=2.43)$ means that this business is profitable to be undertaken, with the average income obtained by the leather cracker industry in a single production process of $R p .7,163,263$. The added value of the business of processing leather crackers is IDR 7,663,263 and the added value per $\mathrm{kg}$ in the production process is $(7,633,263: 141 \mathrm{~kg})$ IDR 58,844.33 which means that every $1 \mathrm{~kg}$ of cow leather processed into cow skin crackers can be given an added value of 58,844 . 33. The value added ratio (RNT) of $63 \%$ means that the value added is high because the RNT is $>50 \%$. means the agro-industry business Making cowhide crackers has good prospects for development. To further increase the added value of the processing agro-industry business (the business of cowhide crackers) the need to further increase operational costs such as the use of fuel, the use of electricity, the purchase of auxiliary materials. In addition it needs new innovations in creating new products that are more attractive to consumers' purchasing power.

Kata Kunci :

Efisiensi Bisnis dan Pengolahan Nilai Tambah Agroindustri

\section{ABSTRAK: Penelitian ini mengambil judul "Analisis Efisiensi dan Nilai Tambah Olahan}

Produk Agroindustri Kerupuk Sapi (Studi Kasus di Seganteng Kota Mataram). Penelitian ini dilakukan dengan mengambil 6 unit usaha yaitu usaha pengolahan kerupuk sapi di Seganteng Kecamatan Sandubaya, Kota Mataram yang ditentukan dengan sengaja. Tujuan dari penelitian ini adalah menganalisis tingkat biaya dan pengeluaran produksi, efisiensi biaya dan nilai tambah atau Value Added Ratio (RNT). Secara keseluruhan dari 6 unit usaha agroindustri pembuatan kerupuk, sedangkan tingkat rasio usaha ( $R$ / C Ratio) rata-rata nilainya diatas 1 atau $R$ / C. Rasionya $>1$ yang dimaksud dengan kedua usaha pengolahan kerupuk kulit $(R / C$ Ratio $=2,43)$ artinya usaha ini menguntungkan untuk dilaksanakan, dengan pendapatan rata-rata yang diperoleh industri kerupuk kulit dalam sekali proses produksi sebesar Rp. 7.163.263. Nilai tambah usaha pengolahan kerupuk kulit sebesar $\mathrm{Rp} 7.663 .263$ dan nilai tambah per $\mathrm{kg}$ dalam proses produksinya sebesar (7.633.263: $141 \mathrm{~kg}$ ) Rp58.844,33 yang artinya setiap $1 \mathrm{~kg}$ kulit sapi yang diolah menjadi kerupuk kulit sapi dapat diberikan nilai tambah 58.844. 33. Rasio pertambahan nilai (RNT) sebesar 63\% artinya nilai tambah tinggi karena RNT> 50\%. Sarana Usaha Agroindustri Pembuatan kerupuk kulit sapi memiliki prospek yang baik untuk dikembangkan. Untuk lebih meningkatkan nilai tambah usaha agroindustri pengolahan (usaha kerupuk kulit sapi) perlu lebih meningkatkan biaya operasional seperti penggunaan bahan bakar, penggunaan listrik, pembelian bahan penolong. Selain itu perlu adanya inovasi baru dalam menciptakan produk baru yang lebih menarik bagi daya beli konsumen. 
Corresponding Author:

Alamat : Program Studi Ekonomi Pembangunan, Fakultas Ekonomi dan Bisnis, Universitas Mataram, Jln. Majapahit No. 62 Mataram.

e-mail: Supriyanto@unram.ac.id

2020, EKONOBIS All right reserved 


\section{PENDAHULUAN}

Latar Belakang

Pengembangan agroindustri merupakan keharusan dalam rangka menuju masyarakat industri yang berbasis pertanian, baik agroindustri berskala besar maupun agroindustri berskala kecil seperti agroindustri rumah tangga. Agribisnis dan agroindustri dua kegiatan usaha dibidang pertanian yang mampu menaikkan pendapatan masyarakat baik dipedesaan maupun diperkotaan serta dapat menampung tenaga kerja non skill yang cukup besar. Menurut Midayanto (2014) mendifinisikan agroindustri dalam dua hal, yaitu pertama agroindustri sebagai industri yang berbahan baku utama dari produk pertanian dan kedua agroindustri sebagai suatu tahapan pembangunan sebagai kelanjutan dari pembangunan pertanian tetapi sebelum tahapan pembangunan tersebut mencapai tahapan tahapan pembangunan industri.

Kegiatan agroindustri ini umumnya melibatkan usaha kecil dan menengah yang merupakan kegiatan ekonomi rakyat yang berskala kecil dengan berbagai kekurangan dan kendala yang dimilki oleh kelompok usaha kecil dan menengah ini. Namun pengalaman menunjukkan bahwa usaha kecil atau industri kecil dan menengah memiliki ketangguhan terhadap goncangan perekonomian global, disamping itu jugan industri kecil dan menengah memiloiki kemampuan yang cukup besr untuk menyediakan lapangan pekerjaan, membuka peluang usaha, menyerap tenaga kerja serta memberi pendapatan kepada masyarakat untuk menjamin kehidupan yang lebih sejahtera.

Nusa Tenggara Barat sebagai salah satu daerah penyangga pangan nasional yang berbasis pada pengembangan sektor pertaanian khususnya tanaman padi, palawija, sayuran, umbi umbian dan hasil ternak memiliki potensi yang cukup besar dalam pengembangan agribisnis dan agroindustri pengolahan input pertanian. Hasil olahan dari input pertanian ini disamping dapat memenuhi kebutuhan masyarakat lokal dan juga untuk memenuhi permintaan dari daerah lain termasuk dalam menunjang kegiatan sektor pariwiswata dalam bentuk wisata kuliner dan oleh-oleh produk makanan khas NTB. Khususnya di kota Mataram sebagai pusat pemerintahan dan perdagangan terdapat berbagai industri kecil dan menengah yang bergerak diberbagai bidang pengolahan input pertanian salah satunya adalah industri 
pengolah bahan makanan. Data yang industri kecil unggulan tersebar dl wilayah kami liris dari kantor Dinas Perindustrian kota Mataram yaitu sebagai berikut: kota Mataram memuat beberapa klaster

Tabel 1. Klaster industri unggulan di kota Mataram tahun 2017

\begin{tabular}{|l|l|l|c|}
\hline No & \multicolumn{1}{|c|}{ Jenis Industri } & \multicolumn{1}{|c|}{ Wilayah Pengembangan } & Jumlah Usaha \\
\hline 1 & Kerajinan Mutiara Emas dan Perak & Sekabela dan Kamasan & 224 \\
\hline 2 & Kerupuk Kulit & Seganteng & 9 \\
\hline 3 & Tahu dan Tempe & AbianTubuh & 66 \\
& & Kekalik Grisak & 227 \\
\hline 4 & Industri Kerajinan Logam & Babakan & 8 \\
\hline 5 & Kerajinan Kayu dan Cukli & Sayang-sayang & 25 \\
\hline 6 & Konveksi dan Bordir & Pagutan & 17 \\
\hline 7 & Kerajinan Kulit kerang dan Tanduk & Pagutan & 990 \\
\hline 8 & Makanan Olahan & 6 Kecamatan & - \\
\hline
\end{tabular}

Sumber : Dinas Perindustrian Kota Mataram

Dari tampilan data di atas sebagian besar industri pengolahan bahan makanan yang berkembang di kota mataram kemudian industri tahu dan tempe yang berada diwilayah abian tubuh dan kekalik grisak sebagai sentra pengolahan bahan baku kedelai untuk diolah menjadi produk Tahu dan Tempe walaupun harga input kedelai mengalami pluktuasi namun usaha ini masih tetap berjalan. Selanjutnya usaha kerajinan mutiara emas dan perak sebagai produk oleh-oleh yang cukup dikenal masyarakat luar daerah NTB dengan mutiaranya yang ada di Sekarbela, kemudia industri logam, konveksi dan industri kerupuk kulit yang jumlahnya masih sedikit dan perlu untuk dikembangkan kedepannya.

Industri kecil dikota Mataram sebagian besar memiliki kedekatan secara ekonomi dan sosial dengan masyarakat petani karena input bahannya berasal dari hasilhasil pertanian seperti kedelai untuk kebutuhan agroindustri tahu dan tempe, umbi-umbian untuk usaha keripik singkong, kerupuk kulit dan lain sebagainya. Kebutuhan akan bahan baku untuk memenuhi usaha agroindustri cukup besar dan pasokannya harus tetap tersedia dipasaran. Sampai sejauhmana produk usaha agroindustri unggulan ini dapat memenurhi permintaan konsumen dengan semakin bertambahnya penduduk 
diperkotaan, maka perlu dilakukan penelitian tentang "Analisis Efisiensi usaha Dan Nilai Tambah produk agroindustri olahan Kerupuk Kulit Sapi di Seganteng Kota Mataram".

\section{Perumusan Masalah}

Dari uraian gambaran latar belakang di atas dapat dirumuskan permasalahan penelitian sebagai berikut :

1. Seberapa besar nilai usaha produk agroindustri olahan kerupuk kulit sapi yang dihasilkan dalam sekali proses produksi ditinjau dari biaya, produksi, pendapatan.

2. Apakah usaha agroindustri kerupuk kulit sapi ini secara ekonomis layak diusahakan atau tidak dilihat dari efisiensi usaha.

3. Seberapa besar nilai tambah dan Rasio Nilai Tambah (RNT) yang dihasilkan produk agroindustri olahan kerupuk kulit sapi dalam sekali proses produksi

\section{Tujuan Penelitian}

1. Menganalisis seberapa besar produk yang dihasilkan dapat memberi keuntungan bagi pengusaha agroindustri olahan kerupuk kulit sapi di Seganteng kota Mataram

2. Menganalisis apakah usaha agroindustri olahan kerupuk kulit sapi ini layak untuk dikembangkan atau tidak jika dilihat dari B/C ratio nya.
3. Menganalisis tingkat nilai tambah dan rasio nillai tambah (RNT) dari produk agroindustri olahan kerupuk kulit sapi dalam sekali proses produksi

\section{KAJIAN PUSTAKA}

\section{Konsep Industri Pertanian}

Konsep Industri kecil menurut Deperindag bersama dengan BPS mendefinisikan industri kecil adalah kegiatan ekonomi yang dilakukan oleh perseorangan atau rumah tangga maupun suatu badan yang bertujuan untuk memproduksi barang ataupun jasa untuk perniagaan secara komersial, yang memiliki kekayaan bersih paling banyak Rp 200.000.000,- dan mempunyai nilai jumlah lebih besar jika dibandingkan dengan industri besar dan sedang (Soekartawi 2002).

Seiring dengan perkembangan dan kemajuan zaman serta perkembangan ilmu pengetahuan dan teknologi (IPTEK) maka akan mengakibatkan terjadinya kecenderungan pola transformasi dari pertanian ke industri, yang diketahui bahwa sektor industri merupakan salah satu penyumbang perekonomian di Indonesia. Salah satunya adalah sektor industri pangan yang mengolah hasil pertanian baik nabati maupun hewani menjadi produk olahan. Khususnya 
industri pangan di Indonesia mempunyai prospek bisnis yang cukup besar kedepan karena keberadaannya selalu dibutuhkan untuk memenuhi kebutuhan masyarakat akan barang makanan, karena kebutuhan akan pangan merupakan kebutuhan primer bagi manusia yang lebih mendahulukan kebutuhan pangan daripada kebutuhan yang lainnya.

Usaha dibidang pertanian atau lebih dikenal dengan Agribisnis adalah kegiatan yang berhubungan dengan penanganan komoditi pertanian, dalam arti luas yang meliputi salah satu atau keseluruhan dari mata rantai produksi, pengolahan masukan dan keluaran industri (Agroindustri), pemasaran masukankeluaran pertanian dan kelembagaan penunjang kegiatan (Downey \& Erickison, 1987).

Kegiatan Agribisnis tidak terlepas dengan agroindustri yang kegiatan usahanya menggunakan hasil-hasil pertanian sebagai input atau industri pengolahan hasil pertanian dan perdagangan. Pengembangan agroindustri merupakan suatu keharusan dalam rangka menuju masyarakat industri yang berbasis pertanian.

\section{Definisi Agroindustri Pengolahan}

Agroindustri adalah industri yang mengolah komoditas pertanian primer menjadi produk olahan baik produk antara (intermediate product) maupun produk akhir (finish product), termasuk di dalamnya adalah penganan pasca panen, industri pengolahan makanan dan minuman, industri biofarmaka, industri bio-energy, industri pengolahan hasil ikutan (by product) serta industri agrowisata untuk menunjang sektor pariwisata (Dirjen Bina Pengolahan dan Pemasaran Hasil Pertanian, Dep. Pertanian; 2002).

Agroindustri dapat digolongkan ke dalam aktivitas ekonomi yang berorientasikan sumber bahan input (resources oriented) karena bahan mentah merupakan industri yang mengurangi berat (weight losing material) serta mempunyai ciri sebagai berikut :

1. Bahan mentahnya mudah rusak atau busuk sehingga memerlukan pemrosesan atau pembuatan secepatnya.

2. Bahan mentahnya mengalami pengurangan berat setelah mengalami pembuatan dan ini memerlukan lokasi agroindustri (kilang pembuatan) yang dekat sumber bahan mentah untuk menghemat biaya pengeluaran.

Prioritas utama pengembangan agroindustri difokuskan pada sinergi antara keunggulan komparatif 
sumberdaya dengan orientasi pasar, yakni (Departemen Pertanian; 2002: 4):

1. Industri pengolahan hasil perkebunan seperti industri pengolahan minyak sawit dan kelapa, industri coklat olahan, industri gula, industri biji mete olahan, industri kopi bubuk/instan dan industri teh olahan.

2. Industri pengolahan hasil tanaman pangan dan hortikultura seperti industri buah dan sayur dalam kaleng, industri minuman sari buah, industri tepung tapioka dan derivatnya, industri pakan ternak, dan industri makanan ringan.

3. Industri pengolahan hasil peternakan seperti industri susu olahan, industri daging dalam kaleng, dan industri penyamakan kulit.

4. Industri pengolahan hasil ikutan /samping seperti industri agrocomposting, industri pakan ternak, industri coco fiber dan coco peat, industri karbon aktif, industri minuman dari buah jambu mete dan industri nata de-coco dan lain-lain.

\section{Analisis Usaha}

Menurut Hermanto (1993) analisis usaha yang dimaksud untuk mengetahui kekuatan pengelola secara menyeluruh sebagai jaminan atau agunan bank serta usahanyan. Informasi ini penting bagi pengelola dalam kedudukannya terkait dengan kredit, pajak-pajak usaha dan pajak kekayaan.

Tiga unsur utama yang berkaitan dengan analisis usaha secara keseluruhan merupakan analisis keuangan tentang arus biaya dan penerimaan (cash flow), neraca (balance sheet) dan pertelaan pendapatan (income statement).

\section{Analisis Biaya produksi}

Biaya produksi adalah semua pengeluaran ekonomis yang harus dikeluarkan untuk memproduksi suatu barang. Biaya produksi juga merupakan pengeluaran yang dilakukan perusahaan untuk mendapatkan faktor-faktor produksi dan bahan baku yang akan digunakan untuk menghasilkan suatu produk.

Menurut Prasetyo (1998), biaya adalah nilai dari semua masukan ekonomik yang diperlukan yang dapat diperkirakan dan dapat diukur untuk menghasilkan suatu produk.

Biaya adalah sejumlah nilai uang yang dikeluarkan oleh produsen untuk membiayai kegiatan produksi. Dalam proses produksi, faktor-faktor produksi dikombinasikan, diproses dan kemudian menghasilkan suatu hasil akhir yang biasanya disebut produk (Supandi, 1998). Biaya produksi dimaksudkan sebagai jumlah kompensasi yang diterima oleh 
pemilik unsur-unsur produksi yang digunakan dalam proses produksi yang bersangkutan.

Ada empat kategori atau pengelompokan biaya (Soekartawi 1998):

1. Biaya tetap (fixed cost) adalah biaya yang penggunaannya tidak habis dalam satukali masa produksi.

2. Biaya variabel atau berubah-ubah (variabel cost) adalah biaya yang besar kecilnya sangat tergantung kepada biaya skala produksi.

3. Biaya tunai dari biaya tetap dapat berupa air dan pajak tanah , Sedangkan untuk biaya variabel untuk biaya tenaga kerja luar.

4. Biaya tidak tunai (diperhitungkan) meliputi biaya tetap dan biaya tenaga keluarga

Biaya yang digunakan untuk produksi dapat dibedakan menjadi dua macam yaitu :

1. Biaya (eksplisit) adalah biaya yang secara nyata dibayarkan selama proses produksi oleh produsen untuk masukan (input) yang berasal dari luar seperti penggunaan tenaga kerja dan sarana produksi dari luar.

2. Biaya (implicit) adalah biaya dari factor produksi sendiri yangdiikutsertakan dalam proses produksi untuk menghasilkan produk (output).
Termasuk dalam biaya ini antara lain adalah biaya penyusutan. Sewa tanah milik sendiri. Upah tenaga kerja keluarga dan bunga modal sendiri.

Untuk menghitung total biaya produksi dapat dihitung dengan menggunakan rumus:

$\mathrm{TC}=\mathrm{TVC}+\mathrm{TFC}$ .(Soekartawi, 1995)

Keterangan : $\mathrm{TC}=$ Total Biaya (dalam Rupiah)

TVC $=$ Total Biaya Variabel (dalam Rupiah)

TFC = Total biaya Tetap (dalam Rupiah)

Nilai Tambah

Nilai tambah suatu produk adalah hasil dari nilai produk akhir dikurangi dengan biaya antara yang terdiri dari biaya bahan baku dan bahan penolong. Nilai tambah merupakan nilai yang ditambahkan kepada barang dan jasa yang dipakai oleh unit produksi dalam proses produksi sebagai biaya antara Nilai yang ditambahkan ini sama dengan balas jasa atas ikut sertanya faktor produksi dalam proses produksi. Bila komponen biaya antara yang digunakan nilainya semakin besar, maka nilai tambah produk tersebut akan semakin kecil. Begitu pula sebaliknya, jika biaya antaranya semakin kecil, maka nilai tambah produk akan semakin besar.

Menurut Hayami Yaomi (1987) ada dua cara menghitung nilai tambah, (1) nilai 
untuk pengolahan dan; (2) nilai tambah untuk pemasaran. Faktor-faktor yang mempengaruhi nilai tambah untuk pengolahan dapat dikelompokkan menjadi dua yaitu teknis dan faktor pasar. Faktor teknis yang mempengaruhi adalah kapasitas produk, jumlah bahan baku yang digunakan dan tenaga kerja, sedangkan faktor pasar yang mempengaruhi adalah harga output, upah tenaga kerja, harga bahan baku dan nilai input lain selain bahan baku dan tenaga kerja.

Faktor konversi metode hayami menunjukkan banyaknya produk olahan yang dihasilkan dari satu kilogram bahan baku. Koefisien tenaga kerja menunjukkan banyaknya tenaga kerja langsung yang diperlukan untuk mengolah satu satuan input. Nilai produk menunjukkan nilai output yang dihasilkan dari satu satuan input.

Nilai input lain mencakup nilai dari semua korbanan selain bahan baku dan tenaga kerja langsung yang digunakan selama produksi berlangsung. Output adalah pengeluaran produk yang dihasilkan dalam satu kali proses produksi dihitung dalam satuan kilogram. Input adalah pemasukan bahan baku utama yang dibutuhkan dalam satu kali proses produksi yang dihitung dalam satuan kilogram. Tenaga kerja adalah jumlah orang yang melakukan proses produksi dalam satu kali proses produksi. Faktor konversi merupakan pembagian dari output dengan Input dalam satu kali proses produksi. Koefesien tenaga kerjadi peroleh dari hasil bagi antara tenaga kerja dengan input. Harga output adalah harga produk misal keripik ubi kayu per kg dalam satuan Rupiah. Upah tenaga kerja langsung, merupakan seluruh biaya untuk tenaga kerja dibagi jumlah tenaga kerja yang digunakan dalam satu kali proses produksi dalam satuan Rupiah. Dasar perhitungan dari analisis nilai tambah adalah per kg hasil, standar harga yang digunakan untuk input/bahan baku dan produksi ditingkat produsen.

Analisis nilai tambah metode Hayami merupakan metode yang memperkirakan perubahan nilai bahan baku setelah mendapatkan perlakuan. Nilai tambah yang terjadi dalam proses pengolahan merupakan selisih dari nilai produksi dengan biaya bahan baku dan input lainnya.

Suatu Agroindustri diharapkan mampu menciptakan nilai tambah yang tinggi selain mampu memperoleh keuntungan yang berlanjut. Nilai tambah yang diperoleh dari pengolahan merupakan selisih antara nilai komoditas yang mendapat perlakuan pada suatu tahap 
dengan nilai korbanan yang harus dikeluarkan selama proses produksi terjadi. Menurut Sudiyono (2004), Nilai tambah yang diperoleh lebih dari $50 \%$ maka nilai tambah dikatakan besar dan sebaliknya nilai tambah yang diperoleh kurang dari $50 \%$, maka nilai tambah dikatakan rendah/kecil.

\section{Rujukan Penelitian}

Beberapa hasil penelitian berikut ini yang menjadi dasar dilakukan penelitian Nilai tambah produk agroindustri pengolahan kulit sapi menjadi kerupuk kulit sapi yaitu :

1. Wiyono (2015), "Analisis pendapatan dan nilai tambah usaha tahu pada industri rumah tangga (Uajianto) di desa Ogarandu Kecamatan Bolano Lambunu Kabupaten Perigi Mounton". Hasil penelian dalam pembahasan baha pendapatan yang diperoleh industri rumah tangga "Uajianto" dalam industri tahu selama bulan agustus sebesar $\mathrm{Rp}$ 28.000.000,dengan nilai tambah sebesar $\mathrm{Rp}$ $10.337,72 / \mathrm{kg}$, hal ini menunjukkan bahwa setiap $1 \mathrm{~kg}$ kedelai setelah mengalami proses produksi mampu memberikan nilai tambah sebesar Rp $10.337,72 / \mathrm{kg}$.

2. Nurmedika A, dkk (2013), penelitian tentang "Analisis pendapatan dan nilai tambah keripik nangka pada industri rumah tangga Tiara di Kota Palu". Hasil penelitian diperoleh penerimaan industri rumah tangga Tiara dalam proses produksi keripik nangka selama bulan juli tahun 2012 sebesar Rp 58.500.000,-pendapatan sebesar Rp 36.307.614,25 dan nilai tambah sebesar Rp 33.169/kg.

3. Mar'atissholikhah, dkk (2013), penelitian tentang "Analisis nilai tambah industri krupuk tempe skala rumah tangga (Studi kasus desa Lerep Kecamatan Ungaran Barat Kabupaten Semarang)“. Hasil penelitian, dimana besarnya nilai tambah yang diterima industri keripik tempe skala rumah tangga sekali proses produksi perhari adalah $\mathrm{Rp} 38.452,99$ dengan rasio nilai tambah $82,34 \%$, sedangkan nilai koefisien variasi (CV) lebih dari 0,5 yaitu sebesar 2,92 dan nilai batas bawah keuntungan (L) sebesar -Rp 158.012,18 berarti ada kemungkinan resiko merugi sebesar $\mathrm{Rp} 158.012,18$, Sedangkan posisi BEP pada volume produksi $0,067 \mathrm{~kg}$ keripik tempe dengan nilai BEP penerimaan sebesar Rp 1.827,9. Hal ini berarti bahwa industri tempe skala rumah tangga dapat mencapai titik kembali modal pada harga $\mathrm{Rp} 1.827,9$ dan 
memproduksi sebesar 0,067 kg keripik tempe.

Merujuk pada beberapa hasil penelitian tersebut di atas maka dalam penelitian ini berjudul "Analisis Efisiensi dan Nilai Tambah agroindustri Olahan Kerupuk Kulit Sapi di Wilayah Seganteng Kota Mataram". terdapat beberapa kesamaan terkait variabel, metode deskriptif dan menggunakan analisis kualitatif dan kuantitatif.

\section{METODE PENELITIAN}

\section{Jenis Penelitian}

Jenis penelitian yang digunakan adalah penelitian deskriptif, yaitu suatu metode yang dijalankan dalam penelitian terhadap status kelompok manusia, suatu obyek, suatu set kondisi, suatu sistem pemikiran ataupun suatu kelas peristiwa pada masa sekarang (Nazir; 2001). Penelitian ini bertujuan untuk membuat gambaran atau lukisan secara sistematis, faktual dan akurat mengenai kondisi pengusaha agroindustri pengolahan kerupuk kulit di Seganteng kota Mataram.

\section{Tempat dan Waktu Penelitian}

Penelitian ini dilaksanakan di Seganteng Kecamatan Sandubaya Kota Mataram yaitu Usaha kerupuk Kulit di Seganteng. Pemilihan lokasi penelitian didasarkan pertimbangan bahwa daerah Seganteng merupakan sentra industri pengolahan kulit sapi menjadi kerupuk kulit sapi di kota Mataram. Penelitian ini dilaksanakan dari bulan Mei sampai Desember 2019.

\section{Jenis Data}

Penelitian ini menggunakan data primer dan data sekunder sebagai pendukung analisis. Data primer yang diambil dalam penelitian ini adalah meliputi identitas responden, data produksi, biaya produksi, bahan baku, tenaga kerja, bahan bakar dan lain-lain. Sedangkan data sekunder diperoleh dari instansi yang terkait seperti jumlah industri kecil di kota Mataram serta publikasi yang ada kaitannya dengan penelitian.

\section{Teknik Pengumpulan Data}

Teknik pengumpulan data dilakukan dengan observasi langsung dan wawancara yaitu dengan mendata langsung perusahaan agroindustri olahan sesuai dengan kebutuhan analisis yaitu ditentukan sampel sebanyak 6 unit usaha agroindustri olahan kerupuk kulit sapi secara purposive, yaitu responden pemilik usaha: Muhaimin (UD. Zaira), H. Najamudin (UD. Senja), Junaidi (UD. Bintang Jaya), Suherman Said (UD.Shinta) dan H. Hamka (UD. Muslim). Informasi data diperoleh melalui wawancara.

\section{Analisis Data}


Data-data yang dikumpulkan dalam penelitian ini akan dianalisis secara kualitatif dan kuantitatif. Penggunaan ananalisis kualitatif untuk mendapatkan gambaran kondisi riil usaha agroindustri olahan di lokasi penelitian. Sedangkan data kuantitatif digunakan untuk menganalisis tingkat efisiensi usaha dan perhitungan biaya produksi dan nilai tambah dalam penelitian ini antara lain :

1. Analisis Penyusutan Peralatan

Biaya penyusutan peralatan produksi dihitung dengan menggunakan Metode Garis Lurus dengan rumus sebagai berikut: $D=P-S / N$

Dimana :

$\mathrm{D}=$ Biaya penyusutan peralatan per tahun

$P=$ Harga awal peralatan $(R p)$

$S=$ Harga Akhir peralatan $(R p)$

$\mathrm{N}=$ Perkiraan Umur ekonomis (tahun)

2. Analisis Biaya Produksi

Biaya produksi merupakan penjumlahan biaya tetap dan biaya variabel. Besarnya biaya produksi dihitung dengan persamaan berikut:

$\mathrm{BP}=\mathrm{BT}+\mathrm{BV}$.

Dimana :

$\mathrm{BP}=$ Biaya Produksi (Rp/tahun)

$\mathrm{BT}=$ Biaya tetap (Rp/tahun)

$\mathrm{BV}=$ Biaya Variabel (Rp/tahun)

3. Analisis Penerimaan (Revenue)
Penerimaan Total atau total Revenue dari usaha agroindustri olahan dapat diperoleh dari hasil perkalian antara jumlah produksi tahu yang dihasilkan dikalikan dengan harga tahu, atau secara matematis dapat di tulis:

$\mathrm{TR}=\mathrm{P} \times \mathrm{Q}$

Dimana:

$\mathrm{TR}=$ Total Revenue (total penerimaan $\mathrm{Rp} /$ tahun)

$\mathrm{Q}=$ Kuantitas $(\mathrm{kg})$

$P=$ Harga tahu per kilogram (Rp)

Keuntungan dihitung dengan rumus :

$\pi=\mathrm{TR}-\mathrm{TC}$

Dimana:

$\Pi=$ Keuntungan usaha industri pengolahan

TR $=$ Total Penerimaan kotor

$\mathrm{TC}=$ Total Biaya produksi

4. Analisis efisiensi Usaha

Perhitungan efisiensi usaha agroindustri yang digunakan adalah Revenue Cost Ratio (R/C Ratio). Menurut Soekartawi (2005) R/C Ratio adalah perbandingan antara total penerimaan dengan total biaya yang menunjukkan nilai penerimaan yang diperoleh dari setiap rupiah yang dikeluarkan. Secara matematis dapat dirumuskan sebagai berikut:

$\mathrm{R} / \mathrm{C}=$ Total Penerimaan(TR)/Total Biaya (TC)

Dimana : 
a. Jika R/C > 1, maka Usaha agroindustri pengolahan menguntungkan

untuk diusahakan;

b. Jika $\mathrm{R} / \mathrm{C}<1$, maka usaha agroindustri pengolahan tidak layak untuk diusahakan (merugi);

c. Jika $\mathrm{R} / \mathrm{C}=1$, maka usaha agroindustri pengolahan dalam posisi tidak untung dan tidak merugi (mencapai titik impas).

5. Analisis Nilai Tambah dengan rumus sebagai berikut (Sudiyono; 2004)

$\mathrm{NTp}=\mathrm{Na}-\mathrm{Ba}$ $B a=(B b+B p+B b p)$

Keterangan:

NTp = Nilai Tambah Produk (Rp)

$\mathrm{Na}=$ Nilai Produk Akhir (Rp)

$\mathrm{Ba}=$ Biaya antara $(\mathrm{Rp})$

$\mathrm{Bb}=$ Biaya bahan baku (Rp)

$\mathrm{Bp}=$ Biaya penyusutan alat $(\mathrm{Rp})$

$\mathrm{Bbp}=$ Biaya bahan penolong (Rp)

Rasio Nilai Tambah (RNT) $=$ NT/NP

Dimana:

RNT = Rasio nilai tambah (\%)

NT = Nilai Tambah (Rp)

$\mathrm{NP}=$ Nilai Produksi $(\mathrm{Rp})$

Keterangan :

a. Jika Rasio Nilai Tambah > $50 \%$, maka nilai tambah produk olahan tinggi b. Jika Rasio Nilai Tambah < $50 \%$, maka nilai tambah produk olahan rendah

\section{HASIL DAN PEMBAHASAN}

\section{Gambaran Umum Agroindustri}

\section{Pengolahan}

Agroindustri sebagai salah satu sub sistem penting dalam sistem agribisnis sangat berperan di dalam menggerakkan perekonomian di daerah perkotaan maupun pedesaan.

Keduanya sangat berperan dalam kegiatan ekonomi dalam rangka untuk mendorong pertumbuhan ekonomi yang tinggi karena produk produk yang dihasilksn dari agro industri pengolahan memiliki pangsa pasar yang luas dan memberikan nilai tambah yang relatif tinggi dalam produk nasional. Disisi lain dikemukakan oleh Saragih (2001) bahwa agroindustri juga dapat menjadi wahana bagi usaha untuk m,engatasi kemiskinan karena daya jangkau dan spektrum kegiatannya yang sangat luas dan beragam bentuknya.

Ciri-ciri agroindustri pengolahan hasil pertanian sebagai berikut (Soekartawi; 1998):

1. Dapat meningkatkan nilai tambah; 
2. Menghasilkan produk yang dapat dipasarkan atau digunakan atau dimakan;

3. Meningkatkan daya saing, dan;

4. Menambah pendapatan dan keuntungan produsen.

Melalui proses pengolahan berbagai input bahan baku produksi pertanian ini akan lebih beragam kegunaannya.

Di kota Mataram keberadaan agroindustri pengolahan berkembang cukup pesat, hal ini dapat kita lihat dari banyaknya dan beragamnya produk produk makanan olahan yang dapat digunakan oleh konsumen maupun untuk dikonsumsi langsung berupa makanan olahan siap saji maupun berupa makanan camilan seperti kerupuk dan lain sebagainya. Produkproduk yang dihasilkan merupakan produk yang sifatnya umum maupun produk yang spesifik lokal, seperti kerupuk kulit sapi, tahu, tempe, ikan pindang, dodol nangka, roti atau kue-kue basah maupun kering, olahan rumput laut dan lain sebagainya. Produk olahan lokal biasanya banyak peminatnya dan dicari oleh pembeli sebagai makanan sehari-hari maupun untuk oleh-oleh khas lombok bagi mayarakat atau tamu maupun woisatawan yang berkunjung ke Mataram.
Aneka ragam produk olahan ini menjadi daya tarik bagi kedatangan wisatawan ke pulau lombok untuk menikmati wisata kuliner khas Lombok. Hal ini secara tidak langsung akan memberi dampak terhadap mayarakat yang berkecimpung di dunia bisnis makanan olahan dan ini akan memberi nilai tambah berupa pendapatan yang diterima oleh mereka yang usahanya bergerak dalam bidang agroindustri pengolahan makanan. Sektor industri pengolahan ini baik sebagai penyangga sektor pariwisata juga dalam rangka untuk menciptakan peluang kerja bagi masyarakat kota Mataram. Hal ini ditunjang dengan semakin membaiknya perekonomian kota Mataram pasca gempa bumi 2018 akan meningkatkan dunia usaha khususnya usaha makanan olahan, disisi lain dengan perbaikan ekonomi ini akan meningkatkan daya beli masyarakat utnuk berbelanja produkproduk olahan yang ditawarkan dengan tingkat harga yang terjangkau.

\section{Proses Produksi}

Proses produksi adalah bagaimana bahan baku diolah atau diproses melalui berbagai macam cara sehingga menghasilkan produk olahan yang siap dikonsumsi. Proses produksi yang dilakukan masing-masing komoditi bahan baku metode dan cara pengolahannya 
berbeda beda satu dengan yang lainnya dan ini semua tergantung dari produk yang di hasilkan. Namun secara umum proses produksi yang dilakukan oleh pengusaha agroindustri olahan kerupuk kulit sapa ini masih sederhana serta kalaupun ada mereka mengkombinasikan metode tradisional dengan teknologi, namun jumlahnya tidak banyak dan umumnya mereka bekerja masih secara tradisional. Tenaga kerja yang terlibat dalam proses produksi juga melibatkan tenaga kerja keluarga disamping juga tenaga kerja di luar keluarga dengan sistem pengupahan ada yang harian, borongan, atau diupah perunit produk.

\section{Proses Produksi Kerupuk Kulit Sapi}

1. Jenis Peralatan Dan Nilai Penyusutan Peralatan
Penggunaan peralatan dalam proses produksi sangat berperan dalam kegiatan selama dalam proses produksi. Penggunaan peralatan yang tepat akan membantu memudahkan jalannya proses kegiatan produksi. Peralatan yang digunakan terdiri dari berbagai macam jenisnya tergantung dari olahan produk yang dihasilkan dan harga dari masingmasing jenis peralatan juga berbeda. Nilai peralatan yang digunakan nantinya akan dihitung untuk memperoleh nilai penyusutan peralatan dengan melihat umur ekonomis dari peralatan yang digunakan. Berikut nilai penyusutan peralatan dari berbagai produk olahan agroindustri .

Tabel 2. Rata-rata biaya penyusutan pada industri pengolahan kerupuk kulit sapi

\begin{tabular}{|l|c|}
\hline \multicolumn{1}{|c|}{ Jenis Alat } & Penyusutan (Rp)/pp \\
\hline Talenan & 6.000 \\
\hline Wajan besar & 12.500 \\
\hline Pisau & 5.000 \\
\hline Parang & 4.500 \\
\hline Keranjang & 6.500 \\
\hline Ember & 10.000 \\
\hline Bambo & 10.000 \\
\hline Asah besar & 9.000 \\
\hline Asah kecil & 3.500 \\
\hline Gergaji besi & 7.500 \\
\hline Scaler & 23.167 \\
\hline Timbangan gantung & 15.000 \\
\hline Timbangan duduk & 10.417 \\
\hline Total Biaya & 123.074 \\
\hline
\end{tabular}


2. Pengusaha kerupuk kulit dalam proses produksinya menggunakan bahan baku utama dan bahan penolong. Dalam proses produksi agroindustri olahan kerupuk kulit terdiri dari bahan baku utamanya kulit sapi , dan bahanbahan penolong lainnya seperti garam, bawang putih, minyak goreng, masako, gas LPG, plastik pembungkus.

Tabel 3. Rata-rata biaya bahan baku usaha kerupuk kulit sapi di Seganteng

\begin{tabular}{|l|c|c|c|}
\hline \multicolumn{1}{|c|}{ Jenis Bahan Baku } & Jumlah (Kg) & Harga per Satuan & Jumlah (Rp) \\
\hline Bahan Utama : Kulit Sapi & 130 & 27.000 & 3.510 .000 \\
\hline Bahan Penolong : & 5 & & \\
1.Garam & 3 & 10.000 & 50.000 \\
2. Bauang putih & 45 & 30.000 & 90.000 \\
3. Minyak goreng & $20 \mathrm{Bks}$ & 11.000 & 495.000 \\
4. Massako & $4 \mathrm{Tab}$ & 1.000 & 20.000 \\
5. Gas LPG & $3 \mathrm{ball}$ & 45.000 & 72.000 \\
6. lastik & & & 135.000 \\
\hline Total Bahan Penolong & & & 4.372 .000 \\
\hline Rerata Total biaya Bahan Baku & & & \\
\hline
\end{tabular}

Dari data-data pada tabel 2 dapat diketahui bahua komponen biaya bahan itu terdiri dari bahan penolong yang ratarata sebesar Rp 862.000,- sedangkan bahan baku utama yang digunakan adalah kulit sapi basah yang rata-rata sebesar $\mathrm{Rp}$
3.510.000,- sehingga secara keseluruhan jumlah biaya bahan baku dalam pengolahan kerupuk kulit sapi dalam sekali proses produksi reratanya sebesar Rp 4.372.000,-

Tabel 4. Penerimaan hasil penjualan pengusaha kerupuk kulit di Seganteng

\begin{tabular}{|l|c|c|c|}
\hline \multicolumn{1}{|c|}{ Ukuran Produk } & $\begin{array}{c}\text { Jumlah } \\
\text { Satuan }\end{array}$ & $\begin{array}{c}\text { Harga jual Satuan } \\
\text { ( Rp })\end{array}$ & $\begin{array}{c}\text { Nilai Produksi } \\
\text { ( Rp ) }\end{array}$ \\
\hline UD. Zaira (Muhaimin) & $110 \mathrm{bal}$ & 245.000 & 26.950 .000 \\
\hline UD. Senja (H.Najamudin) & $30 \mathrm{bal}$ & 290.000 & 8.700 .000 \\
\hline UD. Bintang Jaya (Junaidi & $50 \mathrm{bal}$ & 230.000 & 11.500 .000 \\
\hline Suherman & $24 \mathrm{bal}$ & 300.000 & 7.200 .000 \\
\hline UD. Shinta ( Said) & 34 bal & 237.500 & $9.500 .000-$ \\
\hline UD. Muslim (H.Hamka) & 35 bal & 260.000 & 9.100 .000 \\
\hline Rata-Rata pendapatan & $\mathbf{4 7}$ bal & $\mathbf{2 6 8 . 6 6 6 , 7}$ & $\mathbf{1 2 . 1 5 8 . 3 3 3 , 3 0}$ \\
\hline Rata-Rata Pendapatan/Kg & $\mathbf{1 4 1 ~ K g}$ & $\mathbf{2 6 0 . 0 0 0}$ & $\mathbf{8 6 . 2 2 9 , 3 1}$ \\
\hline
\end{tabular}

Tabel 3 Menggambarkan jenis produksi kerupuk kulit sapi yang dihasilkan dalam sekali proses produksi yaitu terdiri dari kerupuk kulit biasa ukuran 1 ball $3 \mathrm{Kg}$ dengan niali harga per ball $\mathrm{Rp} 300.000$,produk kerupuk ukuran tipis Rp 260.000, 
ukuran stik $\mathrm{Rp} 300.000$ dan kerupuk kulit setengah matang $\mathrm{Rp} 130.000$,- dengan total rata-rata seluruh penerimaan dalam sekali produksi kerupuk kulit yaitu sebesar $\mathrm{Rp} 12.158 .333,3$ atau rata pendapatan per $\mathrm{Kg}$ dalam sekali proses produksi sebesar $(\operatorname{Rp} 12.158 .333,3: 141)=$ Rp 86.229,31

\section{Pendapatan Pengusaha kerupuk Kulit} Sapi

Dengan demikian maka keuntungan yang di peroleh pengusaha kerupuk kulit UD. Shanti dalam sekali proses produksi adalah :

$$
\begin{aligned}
\Pi & =T R-T C \\
& =12.158 .333,30-(123.074+4.372 .000 \\
+ & 500.000) \\
& =12.158 .333,30-4.995 .070,- \\
& =7.163 .263,0
\end{aligned}
$$

Efisiensi usaha kerupuk kulit, dimana perhitungan efisiensi yang digunakan adalah :

$$
\begin{aligned}
\text { R/C Ratio } & =T R / T C \\
& =12.158 .333,30 / 4.995 .070 \\
& =2,43
\end{aligned}
$$

artinya bahwa jika R/C > 1 maka usaha agroindustri kerupuk kulit menguntungkan untuk diusahakan.

\section{Analisis Nilai Tambah}

Perhitungan seberapa besar nilai tambah yang dihasilkan dari proses agroindustri usaha kerupuk kulit UD. Shinta di Seganteng Cakranegara dilakukan untuk mengetahui besarnya nilai yang ditambahkanpada bahan baku yang digunakan yaitu kulit sapi. Rumus yang digunakan untuk menghitung besarnya nilai tambah adalah:

\section{Efisiensi Usaha}

Tabel 5. Hasil perhitungan nilai tambah dan rasio nilai tambah

\begin{tabular}{|c|l|c|}
\hline No & \multicolumn{1}{|c|}{ Uraian } & $\begin{array}{c}\text { Nilai (Rp/Kg) } \\
\text { per proses produksi }\end{array}$ \\
\hline 1 & Nilai Produksi & 12.158 .333 \\
\hline 2 & Nilai Bahan Baku Kulit sapi & 3.510 .000 \\
\hline 3 & Nilai Bahan Penunjang & 862.000 \\
\hline 4 & Nilai Penyusutan & 123.070 \\
\hline $\mathbf{5}$ & Nilai Tambah & $\mathbf{7 . 6 6 3 . 2 6 3}$ \\
\hline $\mathbf{6}$ & Rasio Nilai Tambah & $\mathbf{6 3} \%$ \\
\hline
\end{tabular}


Jadi besarnya Nilai Tambah sekali proses produksi :

$$
\begin{aligned}
\text { NTp } & =\mathrm{Na}-(\mathrm{Bb}+\mathrm{Bp}+\mathrm{Bbp}) \\
& =12.158 .333-(3.510 .000+123.070 \\
+862.000) & \\
& =12.158 .333-4.495 .070 \\
& =7.663 .263
\end{aligned}
$$

Jadi hasil perhitungan nilai tambah usaha kerupuk kulit UD. Shanti sebesar Rp 7.663.263,- ini berarti bahwa untuk besarnya nilai tambah yang ditambahkan pada bahan baku kerupuk kulit sapi diperoleh dari pembagi antara NT dengan total produksi (Kg), yaitu 7.663.263:141 Kg $=58,844,33$, artinya bahwa setiap $1 \mathrm{Kg}$ kulit sapi yang diolah menjadi kerupuk kulit sapi dapat memberikan penambahan nilai sebesar $\operatorname{Rp} 58,844,33$. Dengan demikian bahwa hasil analisis menunjukkan bahwa usaha agroindustri usaha kerupuk kulit sapi di Seganteng Kota Mataram memiliki prospek yang baik karena usaha kerupuk kulit sapi ini dapat memberikan nilai tambah yang cukup tinggi.

Selanjutnya perhitungan rasio nilai tambah terhadap nilai outputnya yaitu diperoleh dari pembagian antara nilai tambah dengan nilai output yang dinyatakan dalam prosentase (\%). Secara matematis Rasio Nilai Tambah pada industri pengolahan kedelai menjadi produk tempe sebagai berikut :

Rasio Nilai Tambah $=\mathrm{Rp}$ 7.663.263 / Rp $12.158 .333=63 \%$

Ini berarti Rasio Nilai Tambah produk olahan kulit sapi menjadi kerupuk kulit sapi cukup tinggi, karena Rasionya lebih besar dari (>50 \%). Hal ini menunjukkan bahwa apabila hasil perhitungan Rasio Nilai Tambah $>50 \%$, ini menunjukkan bahwa nilai tambah yang dihasilkan lebih besar dari nilai outputnya, dan nilai tambahnya tergolong tinggi. Hal ini berarti bahwa jika dilihat dari rasio nilai tambah maka usaha agroindustri pengolahan kulit sapi menjadi kerupuk kulit sapai memberikan nilai tambah yang cukup tinggi dalam sekali proses pengolahan kulit sapi menjadi kerupuk kuit sapi.

\section{KESIMPULAN}

Hasil penelitian menunjukkan bahwa Usaha industri kerupuk kulit dari ke enam responden rata-rata dalam sekali proses produksi usaha agroindustri pengolahan kerupuk kulit memperoleh pendapatan sebesar $\mathrm{Rp}$ 7.663.333,- dengan menggunakan bahan baku kulit sebanyak $130 \mathrm{Kg}$ kulit basah. Sedangkan Efisiensi usaha atau R/C Rasionya sebesar 2,43, berarti usaha industri pengolahan kulit sapi menjadi kerupuk kulit 
menguntungkan untuk diusahakan. Besarnya Nilai Tambah usaha kerupuk kulit sapi yaitu sebesar Rp 58.844,33, artinya bahwa setiap $1 \mathrm{Kg}$ kulit sapi yang diolah menjadi kerupuk kulit sapi dapat memberikan penambahan nilai sebesar Rp 58.844,33. Rasio Nilai Tambah (RNT) pada industri pengolahan kerupuk kulit sapi sebesar 63\%, artinya bahwa nilai tambahnya tergolong tinggi karena rasionya lebih besar dari 50\% (RNT>50\%). Agroindustri pengolahan kulit sapi diupayakan untuk mengembangkan produk nya agar lebih inovatif baik dari rasa maupun kemasan produknya, baik yang produk olahan kerupuk sapi setengah matang maupun produk kerupuk kulit sapi goreng berupa stick dan kerupuk sapi biasa.

\section{DAFTAR PUSTAKA}

.............., 2013. Dinas Tenaga kerja Kota Mataram

; Dirjen Bina Pengolahan dan Pemasaran Hasil Pertanian, Dep. Pertanian, 2002.

Arikunto, Suharsini. 2006. Prosedur Penelitian. Suatu pendekatan Praktik. PT. Reneka Cipta. Jakarta

Aryo Demarto,dkk.2003. Sektor informal alternatip kesempatan kerja Bagi Golongan Berpendidikan Rendah. Makalah Diklat Universitas Sebelas Maret.

Hayami, Kaage, dkk. 1987. Agricultural Marketing and Processing in Upland Java. A Perspective From a Sunda Village. CGPRT. Bogor.

Kartasasmita M. 2011. Pengertian Agroindustri. Blogspot.com. 2011

Mubyarto.1998; Konsep Biaya Industri Kecil. Gramedia Jakarta

Mar'atissholikhah, dkk. (2013); Analisis Nilai Tambah Industri Keripik Tempe Skala Rumah Tangga. Jurnal IImu-IImu Pertanian Vol 9 No 2 (2013)

Nasir, Mohammad; 1999. Metode Penelitian sosial. Graha Indonesia. Jakarta.

Nurmedika. A. Marhauati. M. Max Nur Alam. 2013. Analisis Pendapatan dan Nilai Tambah Keripik Nangka pada Industri Rumah Tangga Tiara di Kota Palu. Agrotekbis Vol. 1 No. 3. 2013

Putong Iskandar. 2002. Pengantar Ekonomi Mikro dan Makro. Galia Indonesia

Santri Y, M. 2009. Analisis Usaha Agroindustri Keripik Belut di Kabupaten Klaten. Program Studi Agribisnis Fakultas Pertanian Universitas Sebelas Maret Surakarta.

Sudiyono. 2004. Pemasaran Pertanian .UMM Malang

Sukartawi. 2003. Agribisnis. Teori dan Aplikasinya. PT. Raja Grafindo Persada Jakarta.

Sukartawi. 2001. Pengantar Agroindustri .Penerbit PT. Raja Grafindo Persada. 
Uiyono Tuso, Rukhavina Baksh (2015). Analisis Pendapatan Dan Nilai Tambah Usaha Tahu Pada Industri Rumah Tangga Uujianto Didesa Ogurandu Kecamatan Bolundo. Agrotekbis Vol 3. Juni 2015. 